\title{
PASAL 54 KITAB UNDANG-UNDANG HUKUM ACARA PIDANA DALAM ELABORASI HUKUM PIDANA ISLAM
}

\author{
Diah Ratri Oktavriana ${ }^{1}$ \\ Nasiri $^{2}$ \\ 1STAI Syaichona Moh. Cholil Bangkalan, Indonesia \\ ${ }^{2}$ STAI Taruna Surabaya \\ 1diahratri3@gmail.com \\ 2nasiri.abadi20@gmail.com
}

\begin{abstract}
This research is a normative research. One of the fulfillment of human rights is justice in equalizing the position of every citizen before the law, as stated in Article 27 paragraph (1) of the 1945 Constitution of the Republic of Indonesia. The right to equality before the law or what is commonly referred to as equality before the law is a principle that provides recognition and protection of human rights for every individual regardless of one's background. Therefore, it is true that Law Number 16 of 2011 concerning Legal Aid for People Who Are Less Capable to Guarantee Constitutional Rights of Citizens for Justice and Equality before the Law emerged. Legal aid is a legal service provided by advocates to the community seeking justice In the realm of criminal cases, the provision of legal assistance is described in Article 54 of the Criminal Procedure Code which explains that in the interests of defense, a suspect or defendant has the right to receive legal assistance from one or more legal advisers during the time and at each level of examination. The provision of legal assistance must be based on the principle of equality before the law as stated in the explanation of Law Number 8 of 1981 concerning Criminal Procedure Law. From the various analyzes that have been carried out, in the perspective of Islamic criminal law it can be concluded that the principle of equality before the law as described in Article 54 of the Criminal Procedure Code is equivalent to an order to provide legal aid which in Islamic criminal law is spelled out in Surah Al-Maidah verse 2 which states that as a fellow humans are ordered to help each other as a form of horizontal worship to fellow humans (habl minan-nas). In addition there are many more both in the Al Qur'an and the hadith of the prophet regarding the application of the principle of equality before the law.
\end{abstract}

Keywords: Equality Before The Law, Legal Aid, Islamic Criminal Law.

\section{Pendahuluan}

Perlindungan hak asasi manusia adalah salah satu unsur penting yang harus dimiliki oleh sebuah negara, sebab konsep democratic governance harus dapat mengejawantahkan hak asasi manusia sebagai main 
rule dalam proses berjalannya sebuah negara yang berkeadilan sebagai ciri negara hukum. Tentu ini menjadi pokok pikiran dalam konstitusi bangsa Indonesia, yang kemudian sangat jelas bahwa Indonesia menabsikan diri sebagai negara hukum.

Sebagai negara hukum, Indonesia berkewajiban untuk melindungi dan memastikan bahwa hak asasi manusia dari setiap warga negaranya telah terpenuhi atau justru masih dalam angan-angan. Sebagaimana telah diatur dalam Pasal 28i Ayat (1) Undang-Undang Dasar Negara Republik Indonesia Tahun 1945 (yang selanjutnya disingkat dengan UUD NRI Tahun 1945), bahwa perlindungan, pemajuan, penegakan, dan pemenuhan hak asasi manusia adalah tanggung jawab negara.

Salah satu pemenuhan hak asasi manusia tersebut adalah mengenai konsep keadilan dalam menyamakan kedudukan setiap warga negara di depan hukum. Pasal 27 Ayat (1) UUD NRI Tahun 1945 menyebutkan bahwa segala warga negara bersamaan kedudukannya dalam hukum dan pemerintahan dan wajib menjunjung hukum dan pemerintahan itu dengan tidak ada kecualinya. Tentu ini merupakan sebuah pengakuan serta jaminan perlindungan terhadap pemenuhan hak warga negara mengenai persamaan hak di depan hukum dan pemerintahan.

Hak persamaan di depan hukum atau yang biasa disebut dengan equality before the law merupakan asas yang memberikan pengakuan dan perlindungan terhadap hak asasi manusia bagi setiap individu tanpa membedakan latar belakang seseorang. Oleh karenanya benar kemudian muncul Undang-Undang Nomor 16 Tahun 2011 tentang Bantuan Hukum Bagi Masyarakat Kurang Mampu Untuk Menjamin Hak Konstitusi Warga Negara Bagi Keadilan dan Kesetaraan Dimuka Hukum.

Dikatakan dalam Undang-Undang Nomor 16 Tahun 2011 tentang Bantuan Hukum, bahwa bantuan hukum merupakan instrumen penting dalam sistem peradilan, sebab merupakan legal service yang dapat memberikan perlindungan dan pembelaan terhadap hak-hak konstitusi baik bagi tersangka atau terdakwa sejak ia ditahan sampai ada putusan pengadilan yang bersifat tetap (inkracht). Oleh karenanya, baik tersangka 
atau terdakwa dapat terhindar dari perlakuan buruk atau tindakan tidak terpuji atau bahkan tindakan sewenang-wenang dari aparat penegak hukum.

Asas keadilan dan persamaan di dalam hukum merupakan asas yang memperlakukan semua manusia sama dihadapan hukum dan pemerintahan, oleh karenanya tidak ada diskriminasi baik karena perbedaan suku bangsa, bahasa, jenis kelamin, agama dan/atau kepercayaan, serta adat-istiadat. Hal ini pun berlaku dalam hal kasus pidana, bahwa tersangka atau terdakwa yang dituduh melakukan suatu tindak pidana/kejahatan wajib dianggap tidak bersalah (presumption of innocence) dan tidak boleh dikesampingkan pemenuhan kebutuhannya sebelum ada putusan tetap dari hakim (inkracht). Oleh karenanya perlu ada bantuan hukum sebagai bentuk perlindungan bagi tersangka dalam proses menjalani peradilan pidana guna kepentingan pembelaan.

Perlindungan dan bantuan hukum ini diharapkan akan memberikan keseimbangan dalam suatu proses peradilan pidana, sehingga dapat dicapai keadilan bagi terpidana kelak. Pendampingan oleh penasihat hukum dalam proses peradilan pidana bagi tersangka atau terdakwa sangat penting, dikarenakan seorang tersangka atau terdakwa dalam proses peradilan tersebut walaupun kemerdekaannya dibatasi, ia tetap memiliki hak asasi yang melekat pada dirinya yang pemenuhannya tidak dapat dikesampingkan. Adapun hak asasi bagi terdakwa atau tersangka yang dimaksud seperti tidak dapat disiksa, berhak dijaga martabatnya, berhak dianggap tidak bersalah sebelum ada putusan hakim yang berkekuatan hukum tetap serta hak-hak lain yang melekat pada terdakwa atau tersangka. Hal tersebut sejalan dengan maksud dan tujuan asas equality before the law yang tertuang dalam Pasal 27 ayat (1) UUD NRI Tahun 1945 dan Pasal 3 ayat (2) serta Pasal 5 ayat (1) Undang-Undang Nomor 39 Tahun 1999 Tentang Hak Asasi Manusia.

Mengenai bantuan hukum, tentu ini Islam sangat menganjurkan sebagaimana firman Allah dalam QS Al-Maidah ayat 2 yang artinya: "Dan tolong menolonglah kamu dalam (mengerjakan) kebaikan dan taqwa, dan janganlah kamu tolong menolong dalam (mengerjakan) dosa dan 
permusuhan". Selain itu dalam Islam pemberlakuan asas equality before the law sebagai hak asasi manusia mempunyai landasan yang kuat baik dalam Al-Qur'an maupun dalam Hadits. Asas ini dapat dibuktikan dengan ditentangnya penindasan dan perbudakan atas manusia, yang artinya Islam berbicara mengenai keadilan dan persamaan yang memperlakukan semua manusia sama dihadapan hukum dan pemerintah. Tidak ada diskriminasi karena perbedaan bangsa, suku bangsa, bahasa, jenis kelamin, agama dan kepercayaan, serta adat-istiadat. Oleh karenanya, dapat disimpulkan bahwa output dari pemberlakuan asas equality before the law adalah keadilan. Sebagaimana Allah menjelaskan dalam surat Al Maidah ayat 8 yang artinya "Hai orang-orang yang beriman, hendaklah kamu jadi orang-orang yang selalu menegakkan (kebenaran) karena Allah, menjadi saksi dengan adil. Dan janganlah sekali-kali kebencianmu terhadap suatu kaum, mendorong kamu untuk berlaku tidak adil. Berlaku adillah, karena adil itu lebih dekat kepada takwa. Dan bertakwalah kepada Allah, sesungguhnya Allah Maha Mengetahui apa yang kamu kerjakan”.

Islam sebagai agama yang sempurna dan rahmatan lil a'lamin memang sangat menjunjung tinggi nilai-nilai keadilan, persamaan hak (equality before the law) dan menentang diskriminasi, termasuk dalam hal kasus pidana, bagi tersangka yang dituduh telah melakukan suatu tindak pidana, wajib dianggap tidak bersalah dan tidak boleh dikesampingkan pemenuhan kebutuhannya, sebelum ada putusan yang sah dari hakim. ${ }^{1}$ Hal inipun sejalan dengan aturan yang tertuang dalam Pasal 54 Kitab UndangUndang Hukum Acara Pidana, yang menjelaskan bahwa "guna kepentingan pembelaan, tersangka atau terdakwa berhak mendapat bantuan hukum dari seorang atau lebih penasihat hukum selama dalam waktu dan pada setiap

\footnotetext{
${ }^{1}$ Ketentuan ini merupakan penjelmaan dari asas praduga tidak bersalah (presumption of innocence) yang merupakan salah satu asas dalam KUHAP, yaitu setiap orang yang disangka, ditangkap, ditahan, dituntut, dan atau dihadapkan di muka sidang pengadilan wajib dianggap tidak bersalah sampai adanya putusan yang menyatakan kesalahannya dan telah memperoleh kekuatan hukum tetap. Lihat HMA Kuffal. Penerapan KUHAP Dalam Praktik Hukum. Malang: UMM Press. 2011, 146.
} 
tingkat pemeriksaan, menurut tatacara yang ditentukan dalam undangundang ini". ${ }^{2}$

Sebagaimana dijelaskan diatas, bahwa terdapat peraturan perundangundangan sebagai landasan yuridis bagi seorang tersangka atau terdakwa untuk memperoleh perlindungan dan bantuan hukum oleh advokat, mulai sejak tahap penyidikan sampai dengan tahap putusan hakim yang mempunyai kekuatan hukum tetap. Namun alangkah sayangnya, ketika ditelaah lebih lanjut tentang penerapan pemberian bantuan hukum dalam KUHAP, ternyata masih cenderung membeda-bedakan (tidak sepenuhnya menerapkan asas equality before the law) dan dirasa kurang mencerminkan Undang-Undang Nomor 16 tahun 2011 tentang bantuan hukum, karena masih terkandung syarat khusus ${ }^{3}$ bagi seorang tersangka atau terdakwa di dalam memperoleh perlindungan dan bantuan hukum khususnya secara cuma-cuma (prodeo) yang ditunjuk oleh pejabat dalam ruang lingkup peradilan pidana, yaitu tersangka atau terdakwa yang diancam dengan pidana lima tahun atau lebih. Artinya, terdakwa atau tersangka yang diancam hukuman dengan kurang dari lima tahun tidak berhak mendapatkan bantuan hukum secara cuma-cuma. Hal tersebut memang tidak akan menjadi masalah besar bagi tersangka atau terdakwa yang berasal dari kalangan orang kaya, tetapi bagaimana jika kasus tersebut terjadi pada orang-orang dari kalangan tidak mampu.

Selanjutnya penerapan Undang-Undang Nomor 39 tahun 1999 tentang Hak Asasi Manusia terkait asas equality before the law dalam praktik dilapangan masih belum sepenuhnya dijalankan. Sebagaimana disebutkan dalam penjelasan Undang-Undang Nomor 8 Tahun 1981 tentang Hukum Acara Pidana, yang menunjukkan betapa pentingnya asas equality before the law dalam praktik dilapangan khususnya dunia peradilan pidana

${ }^{2}$ Kitab Undang-Undang Hukum Acara Pidana. Grahamedia Press. 2015, 25.

${ }^{3}$ Syarat khusus yang dimaksud sebagaimana bunyi pasal 56 ayat (1) KUHAP yaitu dalam hal tersangka atau terdakwa disangka atau didakwa melakukan tindak pidana yang diancam dengan pidana mati atau ancaman pidana lima belas tahun atau lebih atau bagi mereka yang tidak mampu yang di ancam dengan pidana lima tahun atau lebih yang tidak mempunyai penasihat hukum sendiri, pejabat yang berangkutan pada semua tingkat pemeriksaan dalam proses peradilan wajib menunjuk penasihat hukum bagi mereka. Lihat Kitab Undang-Undang Hukum Acara Pidana, ibid., 26. 
masih belum sepenuhnya dijalankan. KUHP saat ini memang telah menganut due process of law atau sistem hukum yang adil, namun lagi-lagi sering kali mendapatkan benturan pada penerapannya dilapangan.

\section{Konsep Keadilan}

Dijelaskan bahwa istilah keadilan berasal dari kata adil, yang artinya tidak memihak, sepatutnya, dan tidak sewenang-wenang. Prinsip keadilan mengindikasikan bahwa inti tuntutan keadilan ditujukan bagi siapapun, dengan acuan bahwa hak asasi seseorang tidak boleh dilanggar serta harus dihormati, sebab hak ini melekat pada manusia bukan karena diberikan oleh negara melainkan karena martabatnya sebagai manusia yang diberikan oleh Tuhan Yang Maha Esa.

Keadilan dalam konteks hukum berkaitan erat dengan pemahaman legalitas. Dalam pemahaman legalitas, dijelaskan bahwa tiada perbuatan dapat dipidana kecuali atas dasar kekuatan ketentuan pidana menurut undang-undang yang sudah ada terlebih dahulu. adil jika peraturan yang dibuat berlaku secara sama, setara dan tanpa diskriminasi hukum yang diterapkan kepada semua kasus yang menurut peraturannya harus diterapkan. Legalitas secara hukum terhadap peraturan yang diberlakukan mempunyai implikasi yang sama terhadap semua perbuatan yang dilakukan dengan prinsip mengacu kepada isi dari perbuatan itu sendiri, dan dikatakan tidak adil jika penerapan dari peraturan itu tidak diterapkan pada perbuatan yang sama di tempat yang berbeda.

Agama Islam yang di dalamnya sarat dengan tatanan masyarakat dari mulai yang bersifat individual sampai masalah kemasyarakatan dan penalaran logis menawarkan juga nilai-nilai keadilan yang cukup memadai. Namun nilai-nilai tersebut belum tergali secara mendalam, karena image keagamaan yang ada di masyarakat hanya sebatas ritual formal saja. Nilainilai keadilan dalam Islam sangat dijunjung tinggi, oleh karenanya bagi penegak keadilan akan mendapatkan reward dari Allah bukan saja di dunia, tetapi juga di akhirat nanti. 
Masalah keadilan ini banyak dibicarakan dalam Al-Qur'an dalam berbagai konteks. Kata "adil” disebutkan dalam Al-Qur'an sebanyak 28 kali, al-Qisth disebutkan 25 kali , baik dalam bentuk kata kerja ( $f i^{\prime} i l$ ) maupun kata benda (isim), kemidan kata al-wazn dalam bentuk katakerja ( $f$ ' $i l)$ dan kata benda (isim) disebutkan 20 kali dalam Al-Qur'an. Kata al$H u k m$ dengan berbagai variasinya disebutukan sekitar 150 kali.

Adil secara etimologis adalah tengah atau pertengahan. Dalam makna ini pula adil itu sinonim dengan wasth yang darinya terambil kata pelaku (isim fa'il) nya kata wasith yang dipinjam dalam Bahasa Indonesia menjadi "wasit" yang artinya ialah "penengah" atau "orang yang berdiri di tengah-tengah", yang mensyaratkan sikap keadilan. Di samping itu alWasith berarti penengah, pengantara, pemimpin pertandingan sepak bola, pemisah dan lain-lain.

Dalam surat Al-Maidah ayat 8, kata adil diungkapkan dengan kata ta'dilu yang berarti bahwa setiap orang wajib diperlakukan sama tanpa memandang ras, kedudukan sosial, bahkan agama sekalipun. Lebih dari itu, kebencian terhadap suatu kaum atau pribadi, tidak boleh seseorang bertindak tidak adil. Lebih lanjut disebutkan bahwa keadilan lebih dekat kepada ketakwaan. Ini berarti kebenaran harus ditegakkan dan menegakkan kebenaran yang tidak pandang bulu, merupakan perbuatan adil.

Dalam surat Al-Mumtahanah ayat 8, disebutkan kata tuqsithun yang memiliki arti bahwa kita harus berbuat adil kepada setiap manusia, termasuk kepada orang kafir jika orang kafir tersebut tidak memusuhi kita. Demikian pula disebutkan dalam surat Al-Hujurat ayat 9, ada kata al-qisth dalam bentuk kata kerja perintah ( $f$ ' il amar) yang berarti bahwa berbuat adil harus dilakukan dalam segala situasi dan kondisi.

\section{Asas Equality Before The Dalam Hukum Pidana Islam}

Dalam hukum Islam asas equality before the law didasarkan pada teori kehormatan manusia (al-fitrah). Secara alami dan hakiki (fitrah), setiap orang memiliki hak untuk bebas dalam harkat dan martabat. Teori ini dikemukakan oleh Al-Maududi dalam Human Rights in Islam bahwa 
"secara fitrah setiap orang terlahir dalam keadaan bebas dan sama dalam harkat dan martabat". ${ }^{4}$ Penerapan teori ini dilaksanakan secara mutlak, tanpa ada pengecualian. Semua manusia dan golongan disamakan secara utuh, baik antara hakim dan terdakwa maupun antara pemimpin dan bawahan. Artinya, tidak ada pengutamaan atau perbedaan antar manusia, antara yang berkulit putih dan yang berkulit hitam, antara orang Arab dan non Arab. ${ }^{5}$ Hal ini sebagaimana dijelaskan dalam firman Allah SWT dalam Q.S AlHujurat ayat 13, yang artinya: "Hai manusia, Sesungguhnya Kami menciptakan kamu dari seorang laki laki dan seorang perempuan dan menjadikan kamu berbangsa-bangsa dan bersuku-suku supaya kamu saling kenal-mengenal. Sesungguhnya orang yang paling mulia diantara kamu disisi Allah ialah orang yang paling taqwa diantara kamu. Sesungguhnya Allah Maha mengetahui lagi Maha Mengenal". 6

${ }^{4}$ Abul A'la Al-Maududi. Human Rights in Islam. Leicester: Islamic Foundation. 1976, 5.

${ }^{5}$ Teuku Aliyul Imam. 2018. Asas Equality Before The Law Dalam Hukum Positif Ditinjau Menurut Pidana Islam. Darussalam Banda Aceh: Program Sarjana Universitas Islam Negeri ArRaniry Darussalam Banda Aceh. Tidak Diterbitkan.

${ }^{6}$ Dapat dijelaskan penggalan pertama ayat di atas "Sesungguhnya Kami menciptakan kamu dari seorang laki laki dan seorang perempuan" adalah pengantar untuk menegaskan bahwa semua manusia derajat kemanusiannya sama disisi Allah, tidak ada perbedaan antara satu suku dan yang lain. Tidak ada juga perbedaan pada nilai kemanusian antara laki-laki dan perempuan karena semua diciptakan dari seorang laki-laki dan seorang perempuan. Pengantar tersebut mengantar pada kesimpulan yang disebut oleh penggalan terakhir ayat ini yakni "Sesungguhnya orang yang paling mulia diantara kamu disisi Allah ialah yang paling bertaqwa". karena itu, berusahalah untuk meningkatkan ketaqwaan agar menjadi yang termulia disisi Allah. Diriwayatkan oleh Abu Daud bahwa ayat ini turun berkenaan dengan Abu Hind yang pekerjaan sehari-harinya adalah pembekam. Rosulullah meminta kepada Bani Bayadhah agar menikahkan salah seorang putri mereka dengan Abu Hind. Tetapi mereka enggan dengan alasan tidak wajar mereka menikahkan putri mereka dengannya yang merupakan salah seorang bekas budak mereka. Sikap keliru ini dikecam oleh Al-Qur'an dengan menegaskan bahwa kemuliaan di sisi Allah bukan karena keturunan atau garis kebangsawanan tetapi karena ketaqwaan. Ada juga riwayat yang menyatakan bahwa Usaid Ibn Abi Al-Ish berkomentar ketika mendengar Bilal mengumandangkan adzan di Ka'bah bahwa: "Alhamdulillah ayahku wafat sebelum mendengar kejadian ini". Ada lagi yang berkomentar: "Apakah Rosulullah tidak menemukan selain burung gagak ini untuk beradzan?". Apapun sabab nuzul-nya, yang jelas ayat di atas menegaskan asal usul manusia dengan menunjukkan kesamaan derajat kemanusiaan manusia. Tidak wajar seorang berbangga dan merasa lebih tinggi daripada yang lain, bukan saja antara satu bangsa, suku, atau warna kulit dan selainnya, tetapi antara jenis kelamin mereka. Karena kalaulah ada yang berkata bahwa hawwa, yang perempuan itu, bersumber daripada tulang rusuk adam, sedang adam adalah laki-laki dan sumber sesuatu lebih tinggi derajatnya daripada cabangnya, sekali lagi seandainya ada yang berkata demikian itu hanya khusus terhadap adam dan hawwa, tidak terhadap semua manusia, karena manusia selain mereka berdua dan kecuali Isa As. Lahir akibat percampuran laki-laki dan perempuan. Dalam konteks ini, sewaktu haji wada' (perpisahan), Rosulullah SAW berpesan antara lain: "Wahai seluruh manusia, sesungguhnya tuhan kamu esa, ayah kamu satu, tiada kelebihan orang Arab atas non Arab, tidak juga orang non Arab atas orang Arab, atau orang (berkulit) hitam atas yang (berkulit) merah (yakni putih) tidak juga sebaliknya kecuali dengan taqwa. 
Maksud dari ayat diatas setara dengan sabda Rosulullah SAW sebagaimana berikut: "Manusia itu sama seperti gigi sisir, tidak ada keutamaan seorang arab atas orang bukan dari bangsa arab". 7

Sama halnya dalam hukum pidanapun, tidak ada perbedaan atas pemberlakuan hukuman bagi mereka yang telah terbukti melakukan suatu tindak pidana. Mereka sama-sama berhak dan wajib mendapatkan hukuman atau sanksi dari apa yang telah mereka perbuat. Sebagaimana pernah terjadi di masa Rosulullah SAW, seorang wanita dari satu suku yang kuat didakwa kasus pencurian. Beberapa anggota keluarga wanita itu pergi menjumpai Rosulullah SAW untuk meminta pembebasan si wanita tadi dari hukuman yang ditentukan. Rosulullah SAW dengan tegas menolak perantaraan itu dengan mengatakan sesuai hadits "Diberitakan kepada kami dari Said bin Sulaiman, diberitakan kepada kami oleh Lais dari Ibnu Syihab, dari Urwah, dari Aisyah R.A: bahwa orang-orang Quraisy merasa terusik oleh perkara seorang wanita bermarga Makhzumiyyah yang telah mencuri, maka mereka berkata: siapa yang mau membicarakannya kepada Rosulullah dan siapa yang berani berbicara kepada beliau kecuali Usamah yang dikasih Rosulullah SAW? Maka Usamah berbicara kepada Rosulullah SAW, maka Rosulullah berkata: "apakah engkau mau memberi pembelaan pada salah satu ketetapan Allah?" kemudian Rasulullah berdiri menyampaikan pidato lalu beliau bersabda: wahai manusia! Sesungguhnya telah sesat orang-

Sesungguhnya semulia-mulianya kamu di sisi Allah adalah yang bertaqwa. (HR. Al-Baihaqi melalui Jabir Ibn 'Abdillah). Dengan demikian maka dapat ditarik kesimpulan bahwa semua manusia memiliki derajat yang sama meskipun mereka terdiri dari golongan dan bangsa yang berbeda-beda, karena yang membedakan hanyalah ketaqwaannya kepada Allah SWT. Lihat M. Quraish Shihab. Tafsir Al-Misbah : Pesan, Kesan Dan Keserasian Al-Qur'an. Jakarta: Lentera Hati. 2012, 616-617.

${ }^{7}$ Hadits tersebut menyatakan bahwa semua manusia memiliki derajat yang sama meskipun mereka terdiri dari golongan dan bangsa yang berbeda-beda. Mereka mempunyai hak yang sama, kewajiban yang sama, dan tanggung jawab yang sama. Mereka diibaratkan gigi sisir yang rata, antara satu gigi dengan gigi yang lain tidak lebih tinggi atau lebih pendek. Seluruh manusia juga diibaratkan anak dari satu orang tua, kesatuan asal keturunan manusia ini menuntut persamaan hak, kewajiban, dan tanggung jawab. Oleh karena itu tidak ada keutamaan dan perbendaan antar seorang warga negara dengan warga negara lainnya. Dalam hukum Islam, satu-satunya ukuran keutamaan dan perbedaan manusia hanyalah ketaqwaan. Akan tetapi, keutamaan dan perbedaan tersebut dalam batas tertentu, yaitu hanya antara manusia dan Tuhannya. Manusia yang paling mulia di sisi Allah adalah yang paling bertaqwa. Ketaqwaan yang menjadikan seorang manusia mulia di sisi Allah, tidak memberikan hak yang lebih banyak dibandingkan manusia lainnya. Lihat Ahmad Wardi Muclish. Pengantar dan Azas Hukum Pidana Islam (Fiqh Jinayat). Jakarta: Sinar Grafika. 2004, 56. 
orang sebelum kalian yang mana apabila orang terhormat di antara mereka mencuri, maka mereka membiarkannya, namun bila rakyat jelata di antara mereka mencuri, maka mereka memberlakukan hukuman kepadanya. Demi Allah, seandainya Fathimah binti Muhammad mencuri, niscaya Muhammad memotong tangannya".

Berdasarkan Hadits di atas, bahwa asas persamaan di depan hukum (equality before the law) telah dipraktikkan oleh Rosulullah sendiri pada masanya, bahkan beliau dengan jelas dan tegas mengatakan bahwa semua orang yang melakukan suatu perbuatan yang dilarang oleh Allah maka akan dikenai hukuman tanpa memandang siapa yang melakukannya. Syariat Islam juga tidak mengakui pengistimewaan kepada orang-orang tertentu. ${ }^{8}$

Penerapan asas equality before the law dalam hukum Islam juga dapat dilihat pada kisah Jabalah bin Aiham. Jabalah bin Aiham adalah seorang raja Gassan (daerah di antara Hijaz dan Suriah) yang telah memeluk agama Islam. Ia datang ke Mekkah bersama pengiring kuda. Ia mengenakan pakaian kebesaran yang dihiasi emas dan perak. Pada saat thawaf di Ka'bah, tanpa sengaja pakaiannya terinjak oleh seseorang yang berasal dari Fazarah, suatu daerah yang tidak jauh dari Mekkah. Jabalah lalu menampar orang itu, kemudian orang itu pun segera mengadukan kepada Khalifah Umar Ibnu Khathab. Khalifah Umar lalu memerintah penjatuhan hukuman qishas kepada Jabalah, yang mana ia harus ditampar sebagaimana yang telah ia lakukan kepada seseorang yang berasal dari Fazarah. Jabalah membantah dan berkata, "apakah engkau akan menghukumku, padahal aku seorang raja, sedangkan dia orang biasa?”. Kemudian Khalifah Umar menjelaskan, "wahai Jabalah, Islam telah menyamakan antara engkau dan yang lain, tidak ada keutamaan satu atas yang lain kecuali dengan kebaikan". Jabalah pun melarikan diri ke negara romawi dan masuk agama kristen, namun dikemudian hari ia menyesal sebagaimana tersirat dalam syairnya yang berbunyi, "Orang-orang bangsawan menjadi kristen lantaran tamparan. Sebenarnya tidak ada kemudhorotan yang terjadi jika saja aku sabar.. 9

${ }^{8}$ Teuku Aliyul Imam, Op.Cit., 38.

${ }^{9}$ Abdul Qadir Audah. Al-Tasyiri Al-Jina'I Al-Islami Muqaranam Bil Al-Qanun al-Wadh'I, (terjemah Ali Yafie), Ensiklopedi Hukum Pidana Islam. Jilid I. Bogor: PT Kharisma ilmu. 2007, 
Kaidah hukum Islam menetapkan untuk tidak memandang ganti rugi berdasarkan kepribadian korban, jabatan, dan kekayaannya, tetapi menilainya berdasarkan akibat perbuatan terhadap si korban. Karena itu, apabila seseorang terbunuh, baik dari golongan terhormat maupun rakyat biasa, diatnya sama, yaitu satu. Demikian pula apabila seorang buruh dan seorang kepala perusahaan mengalami kecelakaan yang mengakibatkan keduanya sama-sama kehilangan tangan atau jari, keduanya diberi ganti rugi yang sama. ${ }^{10}$

Hukum Islam menerapkan asas equality before the law dalam jangkauan yang lebih luas dari pada nalar manusia. Karena itu, hukum Islam tidak membedakan antara pemimpin atau raja dan rakyat jelata, antara para diplomat dan rakyat biasa, antara orang kaya dan orang miskin. ${ }^{11}$ Satusatunya yang menjadi perbedaan antara manusia dalam hukum Islam adalah ketaqwaannya kepada Allah SWT.

\section{Eksistensi Bantuan Hukum dalam Perspektif Hukum Pidana Islam}

Bunyi Pasal 54 KUHAP yaitu guna kepentingan pembelaan, tersangka atau terdakwa berhak mendapat bantuan hukum dari seorang atau lebih penasihat hukum selama dalam waktu dan pada setiap tingkat pemeriksaan, menurut tatacara yang ditentukan dalam undang-undang ini. Ketentuan yang diatur dalam pasal ini merupakan suatu jaminan bagi tersangka atau terdakwa untuk memperoleh bantuan hukum pada setiap tingkat pemeriksaan dalam peradilan. ${ }^{12}$

Bantuan hukum yang dimaksud adalah jasa hukum yang diberikan oleh advokat kepada kalangan masyarakat pencari keadilan. ${ }^{13}$ Dalam

336. Dapat dijelaskan mengapa khalifah Umar menjatuhkan qishas kepada Jabalah, sebagaiman qishas dalam hadits disebut dengan kata qawad, maksudnya adalah semisal, seumpama (almumatsilah). Adapun maksud yang dikehendaki syara' adalah kesamaan akibat yang ditimpakan kepada pelaku tindak pidana yang melakukan pembunuhan atau penganiayaan terhadap korban. Dalam ungkapan lain, qishah adalah pelaku akan menerima balasan sesuai dengan perbuatan yang dilakukan. Abdul Qadir Audah mendefinisikan qishas sebagai keseimbangan atau pembalasan terhadap pelaku tindak pidana dengan sesuatu yang seimbang dari apa yang telah diperbuatnya. Lihat Rahmat Hakim. Hukum Pidana Islam. Bandung: Pustaka Setia. 2000, 125.

${ }^{10}$ Teuku Aliyul Imam, Op.Cit., 41.

${ }^{11}$ Ibid., 42.

${ }^{12}$ HMA Kuffal. Penerapan KUHAP Dalam Praktik Hukum. Malang: UMM Press. 2011, hlm. 136.

${ }^{13}$ Didi Kusnadi. Bantuan Hukum Dalam Islam. Bandung: Pustaka Setia. 2012, 48. 
hukum pidana, bantuan hukum dilakukan dalam upaya memberikan perlindungan dan pembelaan terhadap hak asasi tersangka atau terdakwa sejak ia ditangkap atau ditahan sampai dengan diperolehnya putusan pengadilan yang telah mempunyai kekuatan hukum tetap, yang dibela dan diberi perlindungan hukum bukanlah kesalahan tersangka atau terdakwa melainkan hak-hak asasi dari tersangka atau terdakwa agar terhindar dari perlakuan dan tindakan tidak terpuji atau tindakan sewenang-wenang dari aparat penegak hukum. ${ }^{14}$

Pada dasarnya, eksistensi atau keberadaan konsep bantuan hukum berkaitan erat dengan ketentuan hukum Islam yang menganjurkan kepada para pemeluknya agar melindungi hak-hak hukum setiap individu, bahwa setiap orang sama kedudukannya di depan hukum (asas equality before the law), dan adanya suatu kewajiban menegakkan hukum dan keadilan bagi setiap individu. Ketentuan hukum Islam tersebut menjadi dasar yang paling fundamental bagi adanya bantuan hukum dalam proses penegakan hukum Islam. ${ }^{15}$

Bantuan hukum dalam istilah literatur hukum Islam disebut dengan al-mahamy ${ }^{16}$ yang berarti membela, mempertahankan, melindungi. ${ }^{17}$ Dikarenakan istilah bantuan hukum berkaitan dengan profesi advokat. Maka al-mahamy dalam hukum Islam setara dengan pengacara, lawyer, konsultan dan penasihat hukum yang memiliki kesamaan fungsi untuk memberi bantuan hukum kepada masyarakat pencari keadilan (klien). Jika dilihat dari konteks sejarah hukum Islam, istilah al-muhamy juga dekat dengan peran kalangan penegak hukum pada zaman awal perkembangan hukum Islam,

\footnotetext{
${ }^{14}$ Arifin Rada, Esensi Keberadan Advokat Menurut Hukum Islam, Jurnal Ahkam Volume XIV Nomor 1, 2014, 120.

${ }^{15}$ Sebagaimana telah dijelaskan oleh Subhi Mahmasani, hak asasi manusia dalam Islam, pada hakikatnya manusia dilahirkan untuk bebas dalam harkat dan martabanya, sehingga setiap manusia memiliki hak yang sama di depan hukum dan berhak pula mendapatkan jaminan keadilan. Lihat Subhi Mahmasani. Hak Asasi Manusia Dalam Islam (terjemah Imam Mahyudi). Jakarta: Rajawali Press. 1996, 15.

${ }^{16}$ Muslim Muhammad Zaudat Al-Yusufi. Ujratu Al-mahamy Fi Dhau'i Asy-Syariat AlIslamy. Cairo: Dar Al-Maktabah Al-Misriyyah. tt, 1. 1997, 300.

${ }^{17}$ A.W. Munawwir. Kamus Al-Munawwir Arab-Indonesia. Surabaya: Pustaka Progresif.
} 
yaitu al-hakam, al-mufti, dan al-mushalih al-alaih (juru damai). ${ }^{18}$ Selain kata al-muhamy, bantuan hukum juga dikonotasikan dengan wakalah. ${ }^{19}$

Wakalah merupakan pemberian kuasa dari seseorang kepada orang lain untuk melakukan suatu perbuatan tertentu yang diperkenankan oleh syariat. ${ }^{20}$ Secara Istilah, wakalah bermakna mewakilkan suatu urusan kepada orang lain. ${ }^{21}$ Sifat wakalah yang mewakili urusan orang lain, identik dengan perwakilan seseorang untuk membantu menyelesaikan sengketa, terutama dalam proses peradilan. Pada kenyataannya, tidak semua orang memiliki kompetensi atau kesempatan untuk menyelesaikan pekerjaan tertentu yang berkaitan dengan kehidupannya. Manusia dalam menyelesaikan urusannya sendiri terkadang membutuhkan keterlibatan pihak lain dalam membantu menyelesaikannya. ${ }^{22}$

Bantuan hukum pada masa sahabat mengalami perkembangan, pada masa pemerintahan Khalifah Umar Ibnu Khattab sudah mulai melimpahkan masalah peradilan pada pihak lain yang memiliki otoritas untuk itu. Lebih dari itu, Khalifah Umar Ibnu Khattab mulai membenahi lembaga peradilan untuk memulihkan kepercayaan umat terhadap lembaga peradilan. Selain adanya lembaga bantuan hukum dengan sebaik-baiknya agar mampu menjadi lembaga alternatif tempat penyelesaian sengketa bagi umat, bahkan Khalifah Umar berhasil menyusun pokok-pokok pedoman beracara di pengadilan (risalah al-qada) yang ditujukan kepada seorang qadi, Abu Musa Al-Asy'ari. ${ }^{23}$

Adapun dasar legalitas yang dipakai oleh Rosulullah SAW serta diterapkan juga oleh Khalifah Umar Ibnu Khattab bahkan sampai sekarang

${ }^{18}$ Didi Kusnandi, Op.Cit., 38.

19 Inda Areskha. 2017. Mewujudkan Keadilan Konstitusional Bagi Fakir Miskin (Bantuan Hukum Perspektif Hukum Islam). Skripsi. Lampung: Program Sarjana Universitas Islam Negeri Raden Intan Lampung. Tidak Diterbitkan.

${ }^{20}$ Ibnu Rusyd. Bidayatul Mujtahid, Jilid 3 Penerjemah Imam Ghazali Said Dan Achmad Zainudin. Jakarta: Pustaka Amani. 2007, 269.

${ }^{21}$ Sayyid Sabiq. Fiqh Sunnah, jilid 3 Penerjemah Asep Sobari dkk. Jakarta: Al-I'tishom. $2008,369$.

${ }^{22}$ Inda Areskha, Op.Cit., 17.

${ }^{23}$ Inda Areskha. 2017. Mewujudkan Keadilan Konstitusional Bagi Fakir Miskin (Bantuan Hukum Perspektif Hukum Islam). Skripsi. Lampung: Program Sarjana Universitas Islam Negeri Raden Intan Lampung. Tidak Diterbitkan, hlm. 20. 
terkait bantuan hukum dan profesi advokat dalam hukum Islam kurang lebih adalah sebagai berikut: ${ }^{24}$

a. Q.S Al-Maidah ayat 2

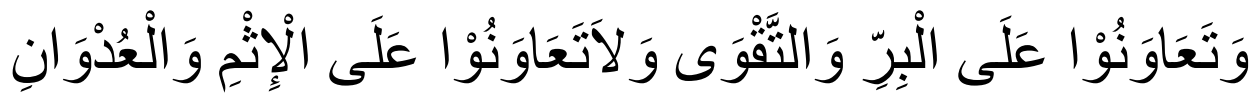

"Dan tolong menolonglah kamu dalam mengerjakan kebaikan dan taqwa, dan janganlah kamu tolong menolong dalam mengerjakan dosa dan permusuhan". ${ }^{25}$

b. Q.S Al-Qoshosh ayat 33-34

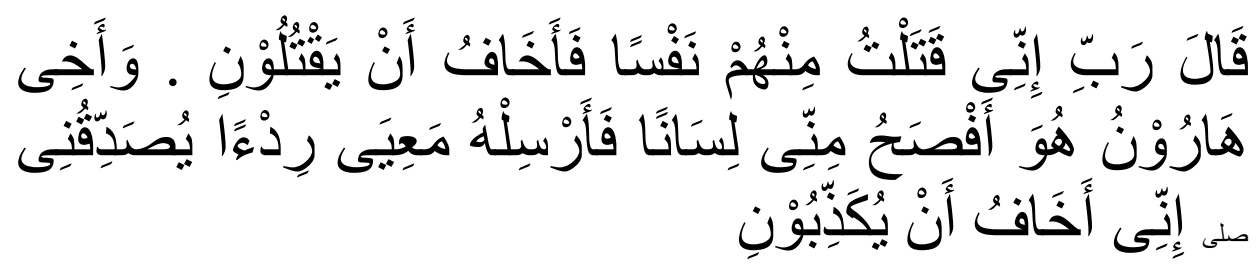

Dia (Musa) berkata: "Ya Tuhanku, sungguh aku telah membunuh seseorang dari golongan mereka sehingga aku takut mereka akan membunuhku. Dan saudaraku, Harun, dia lebih fasih lidahnya daripada aku maka utuslah dia bersamaku sebagai pembantuku untuk membenarkan (perkataan)ku, sungguh aku takut mereka akan mendustakanku”. ${ }^{26}$

c. Q.S Al-Nisa' ayat 58 dan 135

${ }^{24}$ Mahmud Junus. Terjemah Al Qur'an Al Karim. Bandung: PT. Al-ma'arif. 2000, hlm. 98.

${ }^{25}$ Dapat dipahami bahwa ayat tersebut memerintahkan untuk saling tolong-menolong dalam hal kebaikan dan takwa. Lihat Didi Kusnandi, Op.Cit., 58. Diperjelas berdasarkan tafsir ayat "Dan tolong menolonglah kamu dalam mengerjakan kebaikan, yakni segala bentuk dan macam hal yang membawa kepada kemaslahatan duniawi dan atau ukhrowi dan demikian juga tolong menolong dalam ketaqwaan, yakni segala upaya yang dapat menghindarkan bencana duniawi dan atau ukhrowi, walaupun dengan orang-orang yang tidak seiman dengan kamu, dan janganlah kamu tolong menolong dalam mengerjakan dosa dan permusuhan atau pelanggaran". Ayat tersebut merupakan prinsip dasar dalam menjalin kerja sama dengan siapapun (diantaranya advokat dalam memberikan bantuan hukum terhadap kliennya) selama tujuannya adalah kebajikan dan ketaqwaan. Lihat M. Quraish Shihab, Op.Cit., 13-17.

${ }^{26}$ Mahmud Junus, Op.Cit., 353. Dalam ayat di atas dapat dipahami bahwa Nabi Musa meminta bantuan kepada Nabi Harun untuk mendampingi, membela dan melindungi beliau dari kejahatan pembunuhan yang dituduhkan kepadanya. Musa mengganggap Harun lebih pandai berbicara sehingga dianggap mampu mengemukakan argumentasi secara sistematis dan logis. Hal ini menunjukkan bahwa sejak awal Islam telah mengenal konsep pembelaan atau kuasa hukum untuk mengungkap fakta di depan pengadilan. Lihat Arifin Rada, Op.Cit., 117. 


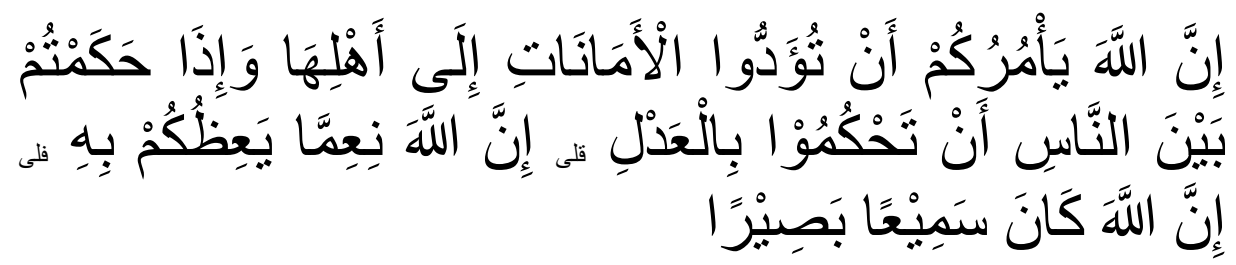

"Sesungguhnya Allah menyuruh kamu menyampaikan amanat kepada yang berhak menerimanya dan menetapkan hukum di antara manusia supaya (menetapkannya) dengan adil. Sesungguhnya Allah memberi pengajaran yang sebaik-baiknya kepadamu. Sesungguhnya Allah adalah maha mendengar lagi maha melihat".

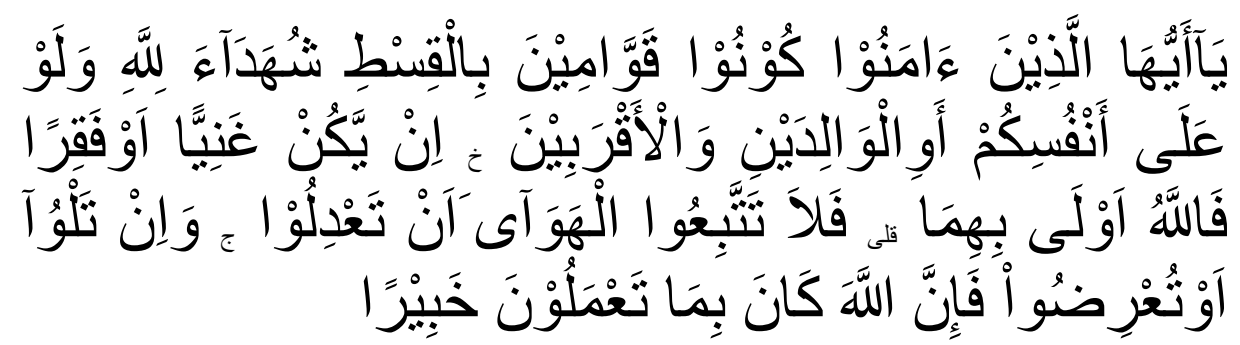

"Wahai orang-orang yang beriman, jadilah kalian penegak keadilan yang menjadi saksi karena Allah walaupun terhadap dirimu sendiri, orang tua atau kaum kerabat kalian. Jika dia (yang terdakwa) kaya atau pun miskin maka Allah lebih tahu kemaslahatan (kebaikannya). Maka janganlah kalian menyimpang dari kebenaran. Dan jika kalian memutarbalikkan (kata-kata) atau menolak menjadi saksi maka sesungguhnya Allah Maha teliti terhadap segala yang kalian kerjakan". 27

d. Q.S Yusuf ayat 26-28

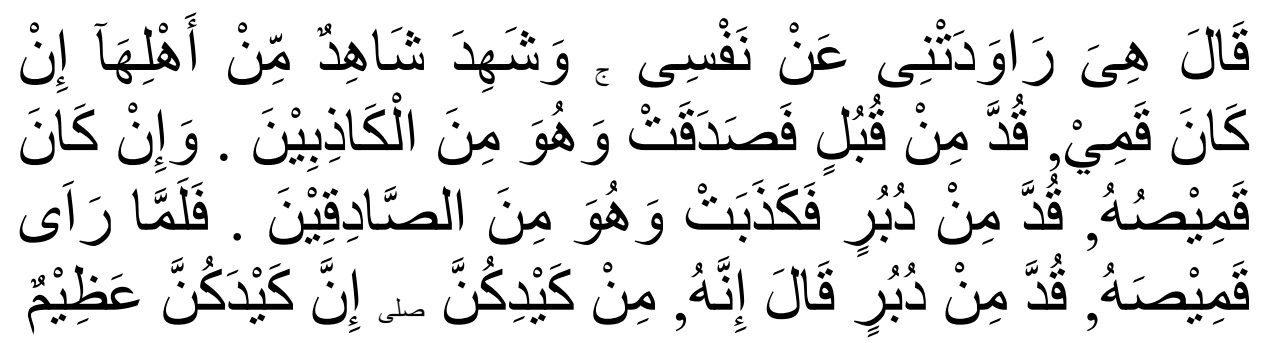

${ }^{27}$ Mahmud Junus, Op.Cit., 59 dan 90. Ayat 58 tersebut dapat dipahami secara tekstual menjelaskan bahwa setiap orang diperintahkan oleh Allah SWT untuk selalu berlaku adil dalam menetapkan segala sesuatu dan menyampaikan amanat kepada yang berhak. Hal ini sesuai dengan konsep dasar advokat yaitu menyampaikan amanat para klien kepada hakim dengan seadil-adilnya. Kemudian pada ayat 135 menjelaskan bahwa pemihakan kepada seseorang hendaknya didasarkan pada prinsip keadilan dan kemaslahatan yang hendak dijunjung tinggi. Disamping itu, dianjurkan agar selalu bersama kaum lemah dan teraniaya. Lemah di sini dapat berarti lemah secara fisik, materi ataupun pengetahuan, termasuk pengetahuan dan kemampuan di bidang hukum. Lihat Arifin Rada, Op.Cit., 117-120. 
Yusuf berkata: "Dia menggodaku untuk menundukkan diriku (kepadanya)". Seorang saksi dari keluarga perempuan itu memberikan kesaksiannya: "Jika bajunya robek di depan maka perempuan itu benar dan Yusuf termasuk orang-orang yang dusta. Dan jika bajunya robek di belakang maka perempuan itulah yang dusta dan Yusuf termasuk orangorang yang benar". Maka ketika suami perempuan itu melihat baju Yusuf robek di belakang dia berkata: "Sesungguhnya (kejadian) itu adalah diantara tipu daya kamu. Sesungguhnya tipu daya kamu adalah besar". ${ }^{28}$

e. Diriwayatkan oleh Al-Hakim

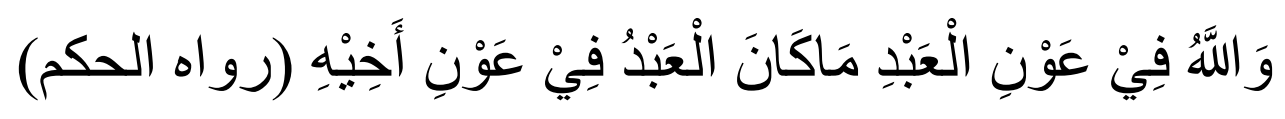

"Dan Allah akan menolong hamba-Nya selama hamba-Nya menolong saudaranya. (H.r. Al-Hâkim)", ${ }^{29}$

f. Diriwayatkan oleh Al-Bukhari

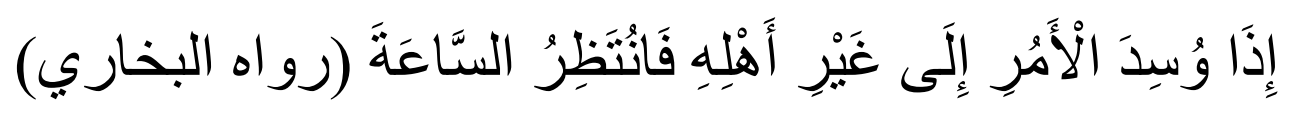

"Apabila kepengurusan itu diserahkan kepada orang yang bukan ahlinya maka tunggulah kehancurannya (H.r. Al-Bukhari)". ${ }^{30}$

g. Diriwayatkan oleh Abu Dawud

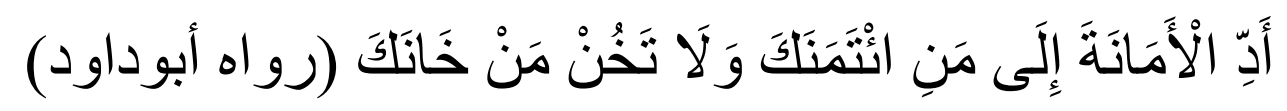

"Tunaikanlah amanah orang yang mempercayaimu dan janganlah kamu mengkhianati orang yang telah mengkhianatimu (H.r. Abu Dawud)". ${ }^{31}$

${ }^{28}$ Mahmud Junus, Op.Cit., 215. Ayat di atas menjelaskan tentang barang bukti yang dipakai dalam persidangan, yaitu pakaian yang robek. Barang-barang bukti seperti itu tidak akan dengan mudah diketahui oleh para pihak yang bersengketa. Untuk itu maka kehadiran advokat/pengacara sangat penting untuk mencari dan menyelidiki hal-hal yang berkaitan dengan barang bukti sebagai bukti yang memperkuat kebenaran yang diinginkan oleh hakim. Lihat Arifin Rada, Op.Cit., 121.

${ }^{29}$ Abu Abdullah Muhammad ibn Muhammad al-Hakim. Al-Mutadarak 'Ala Shahîhayn. Bayrut: Dar Al-Kutub Al-'Ilmiyyah. Cetakan I, Jilid VI. 1410 H, 427. Maksud dari hadits diatas yaitu bertujuan untuk memotivasi agar seorang advokat selalu siap melayani klien yang mengharapkan bantuannya dalam menyelesaikan sengketa. Lihat Arifin Rada, Op.Cit., 116.

${ }^{30}$ Abu Abdullah Muhammad Ibn Ismail Al-Bukhari. Al-Jami'Al-Shahih. Cetakan III, Jilid I. Bayrut: Dar Ibn Katsir. 1407H/1987 M, 33. Dapat dipahami bahwa advokat dalam konteks ini dipandang sebagai seseorang yang mempunyai kemampuan profesional dalam mendampingi orang yang memerlukan bantuan hukum. Seperti yang diungkapkan Rosulullah SAW dalam haditsnya yang mengisyaratkan bahwa bagi orang awam yang hendak menyelesaikan suatu perkara hukum maka dianjurkan untuk mengadukannya kepada orang yang mempunyai keahlian diantaranya yaitu advokat. Sebab jika tidak maka dikhawatirkan hak-hak dalam suatu sengketa akan dirampas oleh orang yang tidak mempunyai hak. Lihat Arifin Rada, Op.Cit., 117.

${ }^{31}$ Sulaiman Ibn Al-Asy'ats Al-Sijistani Abu Dawud. Sunan Abu Dawud. Jilid II. Bayrut: Dar Al-Fikr. 1987, 312. Hadis di atas mengisyaratkan kepada para advokat yang sedang membantu 
Dari beberapa dalil di atas, mengandung makna bahwa sebagai sesama manusia diperintah untuk saling tolong-menolong sebagai bentuk ibadah horizontal kepada sesama manusia (habl minan-nas). Dalam hubungan horizontalnya, manusia tidak akan luput dari pelbagai kesalahan, kealpaan dan kekhilafan yang seringkali menuai kesalah pahaman antara masing-masing individu yang kemudian berimbas pada pertengkaran dan perpecahan. Hal ini terjadi dan muncul karena dalam penyatuan pendapat antara masing-masing individu biasanya bersifat subyektif dan cenderung menguntungkan kepentingan salah satu pihak, sehingga sulit untuk mengambil keputusan yang dapat diterima oleh semua pihak. Maka dengan demikian dalam hal ini dibutuhkan prantara dari pihak ketiga diantaranya yaitu advokat dimana ia akan berusaha untuk menyelesaikan permasalahan berdasarkan prinsip keadilan dan keseimbangan hak bagi kedua pihak yang bermasalah. ${ }^{32}$

5. Implementasi Asas Equality Before The Law Terhadap Penerapan Pasal 54 Kitab Undang-Undang Hukum Acara Pidana (Kuhap) dalam Hukum Pidana Islam

Sebagaimana telah disinggung di atas bahwasanya Pasal 54 KUHAP merupakan salah satu aturan yang menjadi jaminan bagi tersangka atau terdakwa untuk memperoleh salah satu haknya, yaitu bantuan hukum dari advokat pada setiap tingkat pemeriksaan dalam acara peradilan pidana. Salah satu dasar yang memicu terlaksananya bantuan hukum dalam hukum pidana Islam adalah asas persamaan di depan hukum (equality before the law) sebagaimana disebutkan dalam Q.S Al-Hujurat ayat 13.

dan melayani kliennya agar dapat bersikap amanah ketika ia diminta untuk mewakilinya. Lihat Arifin Rada, Op.Cit., 117.

${ }^{32}$ Ibid., 117. 
Ayat tersebut menjelaskan bahwa semua manusia memiliki derajat yang sama, meskipun mereka terdiri dari golongan dan bangsa yang berbeda-beda. Mereka mempunyai hak yang sama, kewajiban yang sama, dan tanggung jawab yang sama. Oleh karena itu tidak ada diskriminasi dan keutamaan antar seorang warga negara dengan warga negara lainnya. ${ }^{33}$ Meskipun mereka tengah terjerat kasus hukum dan berstatus sebagai tersangka atau terdakwa, namun mereka masih mempunyai hak yang tidak boleh dikesampingkan pemenuhannyan diantaranya bantuan hukum.

Penerapan asas equality before the law dalam bantuan hukum terhadap hukum pidana Islam bersumber dari firman Allah SWT salah satunya dalam Q.S Al-Maidah ayat 2, yang mana Allah SWT mewajibkan kepada hambanya untuk saling tolong menolong dalam hal kebaikan. Serta sabda Rosululloh SAW menyatakan barang siapa yang membantu melepaskan seorang mukmin dari suatu permasalahan-permaslahan yang ada di dunia, niscaya Allah SWT akan membantu melepaskan permasalahan-permaslahannya di hari kiamat, dan barang siapa yang mempermudah kesusahan orang mukmin, niscaya Allah akan mempermudah kesusahannya diakhirat kelak.

Tolong-menolong dalam arti memberi bantuan hukum kepada tersangka atau terdakwa dalam hal kasus pidana, bukan berarti agar nantinya jika tersangka atau terdakwa telah terbukti melakukan suatu tindak pidana bisa bebas dan lepas dari tuntutan hukum. Melainkan menolong dengan cara

${ }^{33}$ Lihat Ahmad Wardi Muclish, Op.Cit., 56. 
mendampingi, membela dan membantu tersangka atau terdakwa agar terhindar dari diskriminasi dan kesewenangan aparat penegak hukum.

Berpegang teguh pada asas equality before the law bahwasanya bantuan hukum adalah hak semua orang tanpa harus memandang status sosial seseorang. Seperti halnya kisah Khalifah Umar Ibnu Khattab yang membantu rakyat kecil dari Fazarah yang tidak sengaja menginjak baju kebesaran raja Jabalah bin Aiham dari Gassan yang sedang melakukan thawaf.

Implementasi asas equality before the law terhadap penerapan bantuan hukum dalam hukum pidana Islam ditujukan untuk penegakan hukum dan untuk kemaslahatan. Kemaslahatan bagi manusia yang bisa terpenuhi dengan adanya bantuan hukum tersebut, meliputi kebutuhan daruriyyat (primer) dan kebutuhan hajiyyat (skunder). Bantuan hukum merupakan kebutuhan hajiyyat ketika tidak terjadi masalah hukum. Namun, kebutuhan akan bantuan hukum berubah menjadi kebutuhan daruriyyat, ketika terjadi masalah hukum. ${ }^{34}$ Maka dapat disimpukan tujuan dari bantuan hukum adalah sebagai berikut: ${ }^{35}$

a. Mewujudkan kebutuhan daruriyyat manusia

b. Mengaplikasikan prinsip atau asas tolong-menolong secara universal

c. Membantu seseorang dalam menyelesaikan perkara yang sedang dihadapi

d. Membantu orang yang didzolimi dan mencegah orang yang bertindak zholim

\footnotetext{
${ }^{34}$ Inda Areskha, Op.Cit., 27.

${ }^{35}$ Ibid.,
} 
Asas equality before the law terhadap penerapan Pasal 54 KUHAP yaitu menjamin tersangka atau terdakwa untuk memperoleh bantuan hukum pada setiap proses peradilan, ${ }^{36}$ hal tersebut setara dengan perintah pemberian bantuan hukum dalam hukum pidana Islam yang dijabarkan Q.S Al-Maidah ayat 2, menyatakan bahwa sebagai sesama manusia diperintah untuk saling tolong-menolong sebagai bentuk ibadah horizontal kepada sesama manusia (habl minan-nas). Tolong-menolong yang dilakukan advokat di dalam memberikan bantuan hukum harus didasarkan pada asas equality before the law, sebagaimana tersirat dalam penjelasan Q.S AlHujurat ayat 13 bahwa setiap manusia mempunyai hak yang sama. Dengan adanya persamaan hak tersebut, maka di dalam memperoleh bantuan hukum khususnya dalam kasus pidana adalah hak semua orang tanpa ada batasanbatasan yang mengakibatkan batal dalam pemerolehan bantuan hukum tersebut.

\section{Kesimpulan}

Penerapan asas equality before the law terhadap Pasal 54 KUHAP setara dengan perintah pemberian bantuan hukum dalam hukum pidana Islam yang dijabarkan dalam Q.S Al-Maidah ayat 2, yang menyatakan bahwa sebagai sesama manusia diperintah untuk saling tolong-menolong sebagai bentuk ibadah horizontal kepada sesama manusia (habl minan-nas). Tolong-menolong yang dilakukan advokat di dalam memberikan bantuan hukum harus didasarkan pada asas equality before the law, sebagaimana tersirat dalam penjelasan Q.S Al-Hujurat ayat 13 bahwa setiap manusia mempunyai hak yang sama. Dengan adanya persamaan hak tersebut, maka di dalam pemerolehan bantuan hukum khususnya dalam kasus pidana adalah hak semua orang tanpa ada batasan-batasan yang mengakibatkan batal dalam pemerolehan bantuan hukum tersebut.

Asas equality before the law juga tersirat dalam penjabaran Pasal 4 Undang-Undang Nomor 39 Tahun 1999 tentang HAM bahwa segala warga negara mempunyai hak untuk diakui sebagai pribadi dan persamaan

\footnotetext{
${ }^{36}$ HMA Kuffal, Op.Cit., 136.
} 
dihadapan hukum. Penerapan asas equality before the law terhadap Pasal 54 KUHAP yaitu menjamin tersangka atau terdakwa untuk memperoleh bantuan hukum pada setiap proses peradilan. Dalam HAM pemberian bantuan hukum tersebut merupakan salah satu hak yang harus terpenuhi dan merupakan salah satu akses untuk memperoleh keadilan. Pemberian Jaminan bantuan hukum tersebut didasarkan pada asas equality before the law yang dijabarkan dalam rumusan Pasal 3 ayat (2) bahwa "setiap orang berhak atas pengakuan, jaminan, perlindungan dan perlakuan hukum yang adil serta mendapat kepastian hukum dan perlakuan yang sama di depan hukum”, serta Pasal 5 ayat (1) Undang-Undang Nomor 39 Tahun 1999 Tentang HAM "setiap orang diakui sebagai manusia pribadi yang berhak menuntut dan memperoleh perlakuan serta perlindungan yang sama sesuai dengan martabat kemanusiaannya di depan hukum". Dengan demikian pemerolehan bantuan hukum adalah hak setiap orang tanpa harus memandang strata sosial seseorang, apakah mereka dari golongan orang kaya atau orang miskin, mereka mempunyai hak persamaan dalam derajat yang diperoleh sejak lahir serta tidak boleh dicabut dari seseorang.

\section{Daftar Pustaka}

HMA Kuffal, 2011, PenerapanUHAP Dalam Praktik Hukum. Malang: UMM Press.

Kitab Undang-Undang Hukum Acara Pidana, 2015, Grahamedia Press.

Abul A'la Al-Maududi, 1976 Human Rights in Islam. Leicester: Islamic Foundation.

Teuku Aliyul Imam. 2018. Asas Equality Before The Law Dalam Hukum Positif Ditinjau Menurut Pidana Islam. Darussalam Banda Aceh: Program Sarjana Universitas Islam Negeri Ar-Raniry Darussalam Banda Aceh.

M. Quraish Shihab, 2012, Tafsir Al-Misbah : Pesan, Kesan Dan Keserasian Al-Qur'an. Jakarta: Lentera Hati.

Ahmad Wardi Muclish, 2004, Pengantar dan Azas Hukum Pidana Islam (Fiqh Jinayat). Jakarta: Sinar Grafika. 
Abdul Qadir Audah, 2007, Al-Tasyiri Al-Jina'I Al-Islami Muqaranam Bil Al-Qanun al-Wadh'I, (terjemah Ali Yafie), Ensiklopedi Hukum Pidana Islam. Jilid I. Bogor: PT Kharisma ilmu.

Rahmat Hakim, 2000 Hukum Pidana Islam. Bandung: Pustaka Setia.

Didi Kusnadi, 2012, Bantuan Hukum Dalam Islam. Bandung: Pustaka Setia.

Arifin Rada, 2014, Esensi Keberadan Advokat Menurut Hukum Islam, Jurnal Ahkam Volume XIV Nomor 1

Subhi Mahmasani, 1996, Hak Asasi Manusia Dalam Islam (terjemah Imam Mahyudi). Jakarta: Rajawali Press.

Muslim Muhammad Zaudat Al-Yusufi, tt, Ujratu Al-mahamy Fi Dhau'i Asy-Syariat Al-Islamy. Cairo: Dar Al-Maktabah Al-Misriyyah.

A.W. Munawwir, 1997,Kamus Al-Munawwir Arab-Indonesia. Surabaya: Pustaka Progresif.

Inda Areskha. 2017. Mewujudkan Keadilan Konstitusional Bagi Fakir Miskin (Bantuan Hukum Perspektif Hukum Islam), Lampung: Program Sarjana Universitas Islam Negeri Raden Intan Lampung.

Ibnu Rusyd, 2007, Bidayatul Mujtahid, Jilid 3 Penerjemah Imam Ghazali Said Dan Achmad Zainudin. Jakarta: Pustaka Amani.

Sayyid Sabiq, 2008, Fiqh Sunnah, jilid 3 Penerjemah Asep Sobari dkk. Jakarta: Al-I’tishom. ma'arif.

Mahmud Junus, 2000, Terjemah Al Qur'an Al Karim. Bandung: PT. Al-

Abu Abdullah Muhammad ibn Muhammad al-Hakim, Al-Mutadarak 'Ala Shahîhayn. Bayrut: Dar Al-Kutub Al-'Ilmiyyah. Cetakan I, Jilid VI, 1410.

Abu Abdullah Muhammad Ibn Ismail Al-Bukhari, 1407H/1987 M, Al-Jami' Al-Shahih. Cetakan III, Jilid I. Bayrut: Dar Ibn Katsir.

Sulaiman Ibn Al-Asy'ats Al-Sijistani Abu Dawud, 1987, Sunan Abu Dawud. Jilid II. Bayrut: Dar Al-Fikr. 